\title{
POTENSI PENAMBAHAN NILAI EKONOMI PADA KONVERSI SAMPAH PLASTIK NONEKONOMIS MENJADI BAHAN BAKAR MINYAK ALTERNATIF DENGAN PROSES PIROLISIS
}

Fahrizal Alaydrus ${ }^{1)}$ Arifin $^{1)}$ Andi Hairil Alimuddin ${ }^{2)}$

1)Program Studi Teknik Lingkungan Jurusan Teknik Sipil Fakultas Teknik Universitas Tanjungpura, Pontianak 2)Program Studi Kimia Fakultas Matematika dan Ilmu Pengetahuan Alam Universitas Tanjungpura, Pontianak Email : fahrizalalaydrus@gmail.com

\section{ABSTRAK}

Sampah plastik merupakan sampah dengan timbulan terbesar kedua di Indonesia setelah sampah dapur, dengan laju penguraian yang jauh lebih lama sehingga dibutuhkan upaya untuk mereduksinya. Salah satu pengolahan plastik yang sedang dikembangkan yaitu pirolisis. Pirolisis adalah proses konversi termokimia untuk memutus rantai polimer. Produk dari proses pirolisis plastik dapat digunakan sebagai bahan bakar minyak karena memiliki fraksi yang sama dengan komponen minyak bumi. Sehingga, proses pirolisis tidak hanya dapat mereduksi sampah plastik namun dapat menjadi solusi krisis energi. Penelitian ini bertujuan untuk mengetahui kuantitas dan klasifikasi BBM hasil proses pirolisis dengan bahan baku sampah plastik nonekonomis berdasarkan pengujian parameter fisik, serta mengetahui perubahan nilai ekonomi pada sampah plastik non ekonomis setelah melalui proses pirolisis. Proses pirolisis dilakukan menggunakan reaktor pirolisis dengan diameter $20 \mathrm{~cm}$ dan tinggi $40 \mathrm{~cm}$. Sampel sampah plastik yang digunakan yaitu plastik LDPE berupa kantong plastik hitam dan plastik PP berupa sedotan plastik. Massa sampel plastik yang digunakan sebanyak 500 gram dan dilakukan 3 kali pengulangan. Sampel sampah plastik dipanaskan di dalam reaktor pirolisis selama 45 menit dengan suhu $400^{\circ} \mathrm{C}$. Hasil penelitian yaitu BBM alternatif hasil pirolisis dengan massa 500 gram dengan 3 pengulangan dari plastik LDPE memiliki volume rata-rata $151 \mathrm{~mL}$, sedangkan dari plastik PP memiliki volume ratarata $483 \mathrm{~mL}$. Berdasarkan hasil pengujian, nilai massa jenis rata-rata ketiga sampel BBM alternatif dari plastik LDPE yaitu $0,7422 \mathrm{~kg} / \mathrm{L}$, sedangkan nilai massa jenis rata-rata ketiga sampel BBM alternatif dari plastik PP yaitu $0,7351 \mathrm{~kg} / \mathrm{L}$. Kedua nilai massa jenis tersebut berada pada rentang nilai massa jenis bensin yaitu sebesar $0,7100-0,7700 \mathrm{~kg} / \mathrm{L}$. Selain itu, nilai viskositas rata-rata ketiga sampel BBM alternatif dari plastik LDPE yaitu $0,7800 \mathrm{cP}$, sedangkan nilai viskositas ratarata ketiga sampel BBM alternatif dari plastik PP yaitu 0,7067 cP. Kedua nilai viskositas tersebut mendekati nilai viskositas bahan bakar jenis bensin yaitu sebesar 0,6520 cP. Berdasarkan kedua nilai parameter fisik tersebut, BBM alternatif yang dihasilkan dari sampah plastik LDPE maupun PP tergolong sebagai bahan bakar jenis bensin. Hasil uji stastistik Mann Whitney menunjukkan kualitas BBM alternatif berdasarkan parameter fisik jenis plastik LDPE maupun PP memiliki angka signifikansi $>0,05$. Angka ini mengindikasikan tidak adanya perbedaan yang nyata antara kedua sampel plastik jenis LDPE dan PP berdasarkan parameter massa jenis maupun viskositas. Setelah melalui proses pirolisis, sampah plastik PP berupa sedotan plastik memiliki nilai ekonomi sebesar Rp 215/kg, sedangkan sampah plastik LDPE berupa kantong plastik memiliki nilai ekonomi -Rp 4.074/kg karena biaya produksi BBM alternatif dari kantong plastik melebihi nilai jual produk yang dihasilkan.

Kata Kunci : sampah plastik, pirolisis, bahan bakar minyak, nilai ekonomi

\begin{abstract}
Plastic waste is the second largest waste generated in Indonesia after household waste, with a much longer decomposition rate so that more efforts are needed to reduce it. One of the plastic processing which currently being developed is pyrolysis. Pyrolysis is a thermochemical conversion process for breaking the polymer chain. The product of plastic pyrolysis process can be used as fuel because it has the same fraction as the component of petroleum. Thus, the pyrolysis process is not only able to reduce plastic waste but also able to be a solution for energy crisis. This study aims to determine the quantity and classification of fuel resulted from pyrolysis process of noneconomic plastic waste based on the physical parameters test, and to know the changes in economic value of non-economic plastic waste after going through the pyrolysis process. The pyrolysis process was carried out using a pyrolysis reactor with a diameter of $20 \mathrm{~cm}$ and a height
\end{abstract}


of $40 \mathrm{~cm}$. Plastic waste samples used were LDPE plastic in the form of black plastic bags and PP plastic in the form of plastic straws. The mass of the plastic sample used was 500 grams and 3 repetitions were performed. Plastic waste samples were heated in a pyrolysis reactor for 45 minutes with a temperature of $400^{\circ} \mathrm{C}$. The result of this research are the quantity of alternative fuel resulted by pyrolysis with mass of 500 gram with 3 repetition from LDPE plastic have an average volume of $151 \mathrm{~mL}$, while from PP plastic have an average volume of $483 \mathrm{~mL}$. Based on the test results, average density value of alternative fuel from LDPE plastic on 3 samples is 0,7422 $\mathrm{kg} / \mathrm{L}$, whereas average density value of alternative fuel from PP plastic on 3 samples is 0.7351 $\mathrm{kg} / \mathrm{L}$. These density value are within the range of density value of gasoline which is 0.7100 $0.7700 \mathrm{~kg} / \mathrm{L}$. In addition, the average viscosity value of the 3 alternative fuel samples from LDPE plastics is $0.7800 \mathrm{CP}$, while the average viscosity value of the 3 alternative fuel samples from PP plastic is $0.7067 \mathrm{CP}$. These viscosity values are close to the viscosity value of gasoline fuel with a viscosity value of $0.6520 \mathrm{cP}$. Based on both values of the physical parameters, both alternative fuel generated from LDPE and PP plastics are classified as gasoline fuel. Mann Whitney test results showed that the alternative fuel quality based on the physical parameters of LDPE and PP plastic types have a significance value of $>0.05$. This number indicates there is no evident difference between the two types of plastic samples LDPE and PP based on the parameter of density and viscosity. PP plastic waste in the form of plastic straws has economic value of $R p$ $215 / \mathrm{kg}$, while the LDPE plastic waste in the form of plastic bag has economic value of $-R p$ $4,074 / \mathrm{kg}$ because the production cost of alternative fuel from the plastic bag exceeds the price of the product.

Keywords: plastic waste, pyrolysis, fuel oil, economic value

\section{PENDAHULUAN}

Peningkatan konsumsi energi dan timbulan sampah merupakan dampak tidak langsung pesatnya pertumbuhan penduduk dan ekonomi. Berbagai penelitian dilakukan untuk meningkatkan efisiensi dan efektifitas sistem pengelolaan dan pengolahan sampah di Indonesia. Kementerian Pekerjaan Umum pada tahun 2014 memaparkan bahwa pada tahun 2025 timbulan sampah Indonesia diproyeksikan mencapai 130 ribu ton/hari atau 47,45 juta ton/tahun. Proyeksi tersebut meningkat signifikan dibandingkan data Statistik Persampahan Indonesia tahun 2008 yang menyebutkan bahwa timbulan sampah di Indonesia mencapai 38,5 juta ton/tahun.

Salah satu upaya reduksi sampah pemerintah Indonesia yaitu penggalakkan praktik 3R melalui bank sampah, yang diwujudkan dengan penetapan Peraturan Menteri Negara Lingkungan Hidup RI Nomor 13 Tahun 2012 tentang Pedoman Pelaksanaan Reduce, Reuse, dan Recycle, melalui Bank Sampah. Namun terdapat permasalahan pada praktik reduksi sampah ini, seperti adanya perbedaan antara jenis sampah yang diterima oleh bank sampah dengan jenis sampah yang dominan dihasilkan oleh masyarakat, serta tidak adanya ketetapan mengenai jenis dan nilai ekonomi sampah yang diterima.

Menurut Statistik Persampahan Indonesia tahun 2008, sampah didominasi oleh sampah dapur dan sampah plastik dengan persentase 58\% dan $15 \%$ berturut-turut. Sampah dapur dapat terurai dalam waktu kurang $<6$ bulan, sedangkan sampah plastik memerlukan waktu yang lebih lama untuk terdegradasi, misalnya, kantong plastik terurai dalam 10-20 tahun sedangkan plastik tebal terurai dalam 50-80 tahun. Berdasarkan perbedaan laju timbulan terhadap laju penguraian sampah dapur dan plastik, dapat disimpulkan sampah plastik memerlukan upaya dalam reduksinya.

Pirolisis adalah teknologi penanganan sampah plastik yang sedang dikembangkan. Pirolosis merupakan proses konversi termokimia untuk memutus rantai polimer. Sampah plastik dapat diolah dengan proses pirolisis mengingat plastik ialah polimer dengan Karbon dan Hidrogen sebagai unsur penyusun utamanya. Selain itu, bahan baku yang umum digunakan dalam pembuatan plastik adalah Nafta, bahan yang dihasilkan dari penyulingan minyak bumi atau gas alam. Produk dari proses pirolisis limbah plastik 
dapat digunakan sebagai bahan bakar kendaraan bermotor karena memiliki fraksi yang sama dengan komponen minyak bumi. Sehingga, proses pirolisis tidak hanya dapat mereduksi sampah plastik namun dapat menjadi solusi krisis energi.

Berdasarkan berbagai hal tersebut, penelitian mengenai potensi peningkatan nilai ekonomi sampah plastik yang tidak memiliki daya jual/tukar melalui proses pirolisis dengan kondisi optimum berdasarkan penelitian-penelitian sebelumnya perlu dilakukan. Selain itu, uji konsistensi hasil klasifikasi BBM pirolisis berdasarkan sifat fisiknya turut dilakukan agar ketepatan nilai ekonomi sampah plastik yang akan ditetapkan di bank sampah diketahui. Hasil penelitian diharapkan dapat menjadi pertimbangan bank sampah dalam penentuan nilai ekonomi sampah plastik yang diuji, serta memicu penelitian lanjutan guna mengeksplor potensi energi terbarukan dari sampah plastik.

Tujuan penelitian antara lain mengetahui kuantitas dan klasifikasi BBM hasil pirolisis sampah plastik nonekonomis berdasarkan parameter fisik, serta mengetahui perubahan nilai ekonomi sampah plastik non ekonomis setelah melalui proses pirolisis.

\section{METODOLOGI PENELITIAN}

Penelitian dilakukan dalam skala laboratorium menggunakan Reaktor pirolisis tipe batch reactor berupa drum terbuat dari besi dilapisi stainless stell berbentuk tabung sebagai ruang sampel sampah plastik dan kerucut sebagai freeboard dan wadah kontraksi fluida sebelum masuk ke pipa kondensor. Reaktor berdiameter $20 \mathrm{~cm}$ dan memiliki tinggi $40 \mathrm{~cm}$. Parameter yang diuji antara lain massa jenis dan viskositas yang bertujuan untuk mengklasifikasi bahan bakar minyak alternatif. Pengujian dilakukan 3 kali pengulangan pada sampel sampah plastik dengan jenis plastik yang sama untuk membuktikan tingkat konsistensi hasil pirolisis sampah plastik.

Penelitian dilakukan dengan memanaskan sampah plastik sebanyak 500 gram di dalam reaktor pirolisis selama 45 menit dengan suhu $400^{\circ} \mathrm{C}$. Hasil uap pemanasan dalam tabung reaktor pirolisis akan dialirkan melalui pipa kondensor dan akan mengalami proses kondensasi pada wadah kondensasi yang menghasilkan produk berupa bahan bakar minyak alternatif. Subyek penelitian adalah jenis sampah plastik nonekonomi, yaitu LDPE berupa kantong plastik hitam dan sampah plastik berjenis PP berupa sedotan plastik hitam. Desain alat yang digunakan disajikan pada Gambar 1.

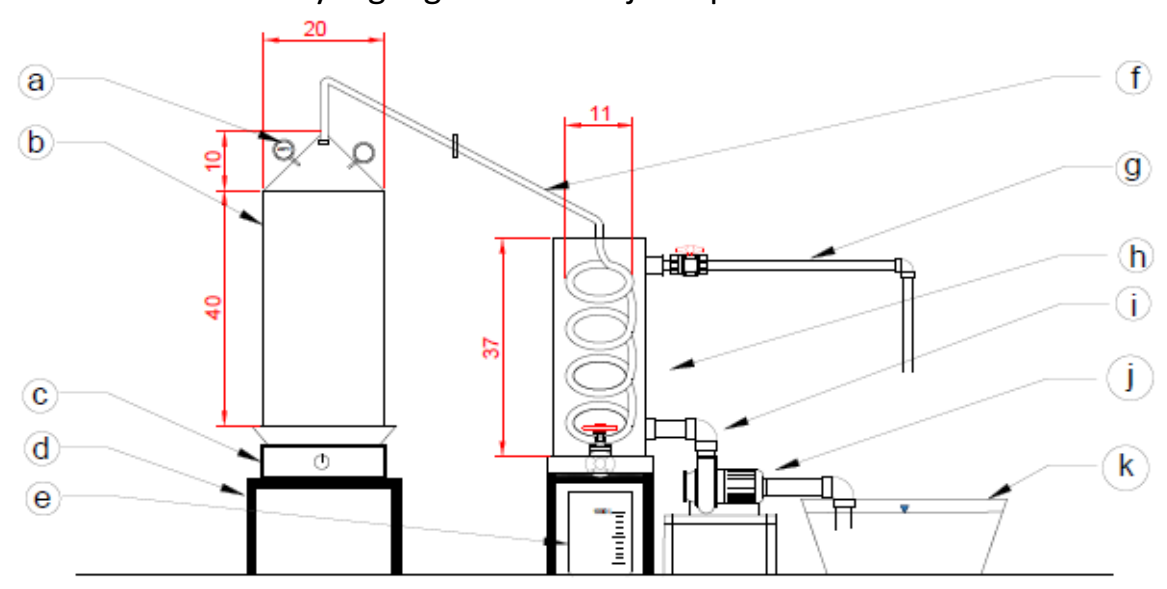

Gambar 1. Desain reaktor pirolisis
a. Termometer $500^{\circ} \mathrm{C}$
b. Reaktor pirolisis
c. Kompor gas LPG
d. Rangka besi

e. Gelas ukur $1000 \mathrm{~mL}$

i. Pipa inlet air dingin

f. Pipa kondensor

j. Mesin pompa air

g. Pipa outlet air dingin

k. Bak penampung air dingin

h. Wadah Kondensasi 


\section{HASIL DAN PEMBAHASAN}

\section{A. KARAKTERISASI PRODUK REAKTOR PIROLISIS}

Dimensi dan pengoperasian reaktor pirolisis mengacu penelitian sebelumnya dimana waktu pirolisis menghasilkan produk terbanyak. Hal ini berkaitan dengan tujuan penelitian dalam hal perubahan nilai ekonomi sampah plastik. Waktu efektif ditetapkan untuk menekan biaya produksi dan meningkatkan nilai ekonomi sampah plastik. Proses pirolisis dilakukan pada suhu $400^{\circ} \mathrm{C}$ stabil, yang optimal dalam menghasilkan minyak pirolisis terbanyak berdasarkan penelitian Ramadhan (2013), dan dalam waktu 45 menit yang merupakan waktu yield (perbandingan massa produk dengan massa bahan awal) produk mencapai kondisi optimum menurut penelitian Tharir (2013). Waktu yield optimum diartikan sebagai waktu kemampuan reaktor pirolisis mencapai titik tertinggi untuk menghasilkan produk, dan apabila melewati waktu tersebut maka massa atau volume produk yang dihasilkan tidak akan mengalami peningkatan secara signifikan.

BBM alternatif dari proses pirolisis sampel plastik LDPE dan PP memiliki karakteristik yang berbeda. Hasil BBM alternatif dari segi warna, BBM alternatif dari plastik LDPE memiliki warna jingga pekat menyerupai warna minyak goreng sedangkan BBM alternatif dari plastik PP memiliki warna kuning pucat yang menyerupai warna bensin. Berdasarkan analisa yang dilakukan Lembaga Minyak dan Gas Bumi (Lemigas), warna minyak dari plastik bekas ini memiliki sifat tidak jenuh. Artinya, perbandingan antara karbon dan hidrogen tidak seimbang sehingga ada mata rantai yang tidak terisi. Produk BBM alternatif dapat dilihat pada Gambar 2.

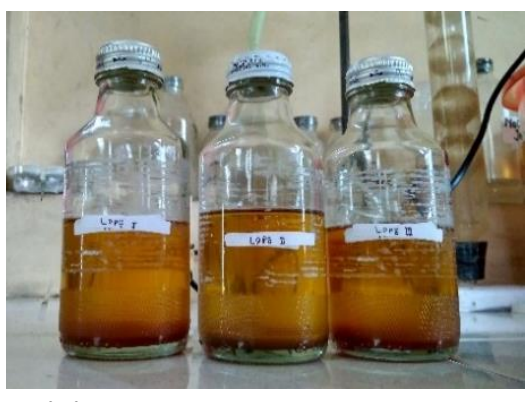

(a) Hasil pirolisis plastik LDPE

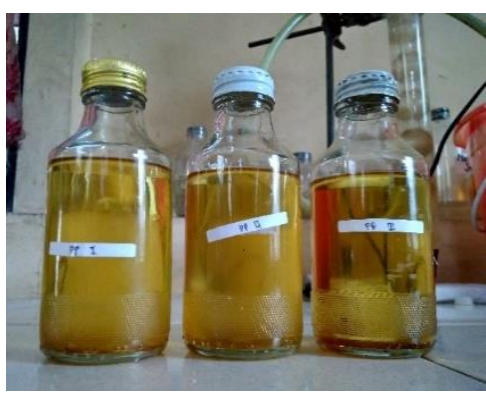

(b) Hasil pirolisis plastik PP

Gambar 2. Produk BBM alternatif hasil pirolisis

Sampah plastik yang dimasukkan ke dalam reaktor pirolisis mengalami perubahan bentuk akibat energi panas menjadi residu dan BBM alternatif. Perubahan massa plastik menjadi produk pirolisis berupa residu dan minyak dari tiap sampel yang diuji disajikan pada Tabel 1 dan Gambar 3.

Tabel 1. Perbandingan Massa Sampel Terhadap Massa Residu dan Massa BBM Alternatif

\begin{tabular}{lccc}
\hline \multicolumn{1}{c}{ Sampel } & Massa Plastik (g) & Massa Residu (g) & Massa BBM alternatif (g) \\
\hline LDPE I & 500 & 300,00 & 106,56 \\
LDPE II & 500 & 313,00 & 115,44 \\
LDPE III & 500 & 305,00 & 113,22 \\
PP I & 500 & 14,13 & 351,50 \\
PP II & 500 & 16,19 & 361,86 \\
PP III & 500 & 16,73 & 359,64 \\
\hline
\end{tabular}

Tabel 1 menunjukkan perbandingan massa sampel plastik sebelum proses pirolisis dan massa produk (residu dan minyak). Massa BBM alternatif merupakan selisih massa 
minyak dengan wadahnya. Berdasarkan hukum neraca massa (Maflahah, 2010), jumlah massa sistem apapun akan tetap walaupun terjadi perubahan bentuk ataupun fisik.

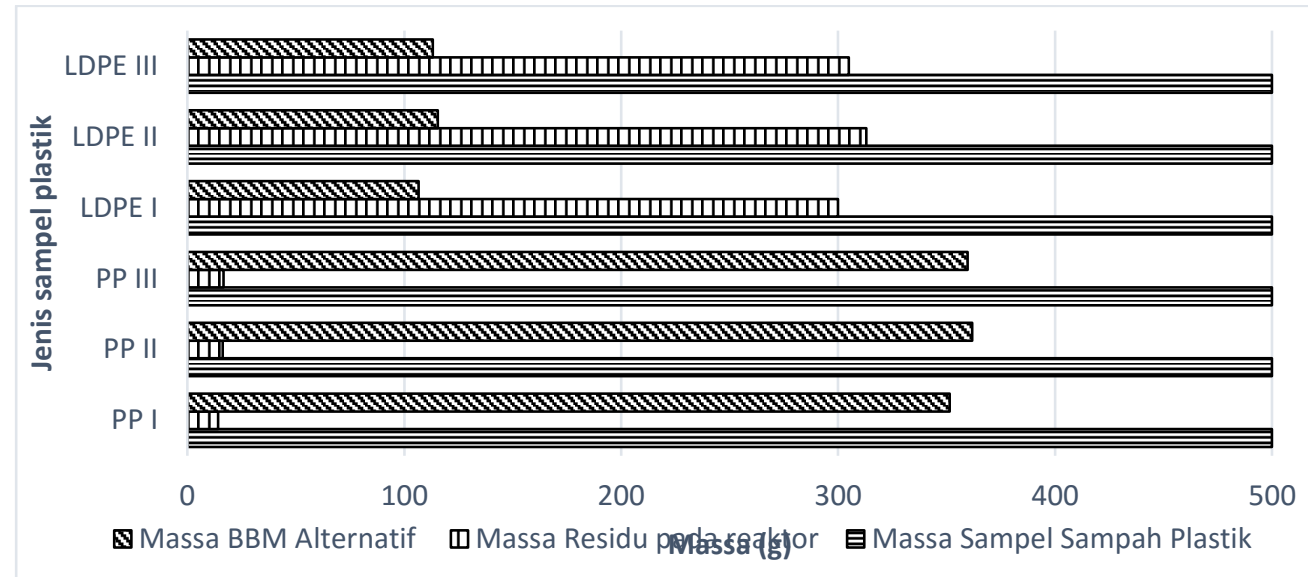

Gambar 3. Perbandingan massa residu dan massa BBM alternatif terhadap massa sampel sampah plastik

Gambar 3 menunjukkan nilai massa plastik tidak sama dengan jumlah massa residu dan massa BBM alternatif. Menurut Wirakartakusumah (1989), jumlah bahan yang masuk akan sama dengan massa yang keluar sebagai produk yang dikehendaki ditambah dengan massa yang hilang dalam proses pengolahan. Artinya, pada proses pirolisis terdapat produk yang tidak terukur berupa gas, sehingga massa sampel plastik dan massa produk tidak sama. Gambar 3 juga menunjukkan nilai produk pirolisis pada sampel LDPE tidak efektif karena massa residu lebih besar dibandingkan dengan massa minyak pirolisis yang dihasilkan. Namun hal ini berbanding terbalik pada sampel PP, dimana massa residu lebih kecil dibandingkan dengan massa minyak pirolisis.

\section{B. KUANTITAS BBM ALTERNATIF HASIL PIROLISIS}

Kuantitas BBM alternatif hasil pirolisis pada penelitian ini dinyatakan dalam perbandingan massa plastik yang digunakan terhadap volume BBM alternatif yang dihasilkan dari proses pirolisis berguna sebagai konversi sampah plastik menjadi BBM alternatif pada analisa perubahan nilai ekonomi. Data kuantitas BBM alternatif pada tiap sampel disajikan pada Tabel 2.

Tabel 2. Perbandingan Massa Plastik Terhadap Volume BBM Alternatif

\begin{tabular}{lcc}
\hline Sampel & $\begin{array}{c}\text { Massa Sampel } \\
\text { Sampah Plastik (g) }\end{array}$ & $\begin{array}{c}\text { Volume BBM Alternatif } \\
\text { yang dihasilkan }(\mathbf{m L})\end{array}$ \\
\hline LDPE I & 500 & 144 \\
LDPE II & 500 & 156 \\
LDPE III & 500 & 153 \\
PP I & 500 & 475 \\
PP II & 500 & 489 \\
PP III & 500 & 486 \\
\hline
\end{tabular}

Tabel 2. menunjukkan bahwa BBM alternatif yang dihasilkan dari proses pirolisis sampel PP memiliki kuantitas yang lebih banyak dibandingkan sampel LDPE. Kuantitas BBM alternatif dari plastik LDPE memiliki volume rata-rata sebesar $151 \mathrm{~mL}$ sedangkan 
BBM alternatif dari plastik PP memiliki volume rata-rata sebesar $483 \mathrm{~mL}$. BBM alternatif dari plastik PP paling banyak dihasilkan pada saat suhu pirolisis sekitar $400^{\circ} \mathrm{C}$. Hal ini sesuai dengan hasil penelitian yang dilakukan Santoso (2010), yang menunjukkan bahwa residu (heavy liquid) dan minyak (light liquid) yang dihasilkan selama proses pirolisis akan menurun bersamaan dengan meningkatnya temperatur, sedangkan gas yang diperoleh akan semakin meningkat ketika temperatur dinaikkan. Ketika sampel plastik PP mengalami pirolisis, pembentukan mencapai titik maksimum pada temperatur $400^{\circ} \mathrm{C}$ setelah itu menurun, sebaliknya heavy liquid menurun dengan semakin meningkatnya temperatur. Hal ini dikarenakan terpecahnya molekul-molekul heavy liquid menjadi light liquid pada temperatur yang lebih tinggi, yang mengakibatkan hasil padatan yang merupakan residu berkurang dan berubah bentuk menjadi minyak.

Sementara itu, BBM alternatif yang dihasilkan dari plastik LDPE hanya memiliki volume sebesar $151 \mathrm{~mL}$ sedangkan residu yang dihasilkan memiliki residu dengan massa rata-rata sebesar 306 gram. Jumlah yield asap cair yang dihasilkan pada proses pirolisis sangat bergantung pada jenis bahan baku yang digunakan dan juga bergantung pada sistem kondensasi yang dipakai. Kondisi ini sesuai dengan yang dikemukakan Tranggono et al (1997) dalam Wijaya, dkk (2008) bahwa untuk pembentukan asap cair digunakan air sebagai medium pendingin agar proses pertukaran panas dapat terjadi dengan cepat. Proses kondensasi akan berlangsung secara optimal apabila air di dalam sistem pendingin dialirkan secara terus-menerus sehingga suhu dalam sistem tersebut tidak meningkat. Rendahnya volume minyak yang dihasilkan dari proses pirolisis terhadap plastik LDPE menunjukkan bahwa pada suhu $400^{\circ} \mathrm{C}$, sampah LPDE diprediksi belum mencapai titik thermal cracking optimum, yang terlihat dari massa produk pirolisis berupa residu yang terbentuk lebih besar dibandingkan massa produk pirolisis berupa minyak atau BBM alternatif. Perbedaan hasil minyak yang didapatkan untuk masingmasing jenis plastik LPDE dan PP dikarenakan dari kedua jenis plastik yang digunakan sudah memiliki karakteristik yang berbeda. Kedua jenis plastik memiliki temperature leleh yang berbeda yaitu untuk jenis plastik LDPE dan PP masing-masing memiliki temperatur leleh sebesar $330^{\circ} \mathrm{C}$ dan $168^{\circ} \mathrm{C}$. Sehingga bisa disimpulkan dari hasil penelitian ini, titik embun yang lebih rendah dimiliki oleh jenis plastik LPDE dibandingkan dengan jenis plastik PP.

\section{KLASIFIKASI BBM ALTERNATIF HASIL PIROLISIS}

Klasifikasi jenis bahan bakar dari proses pirolisis pada sampah plastik LDPE maupun PP dilakukan dengan uji laboratorium parameter fisik BBM alternatif yang dihasilkan. Pengujian dilakukan terhadap 6 sampel BBM alternatif hasil pirolisis yang terdiri atas 3 sampel dari plastik LDPE dan 3 sampel dari plastik PP. Parameter fisik yang diujikan antara lain parameter massa jenis dan parameter viskositas.

Tabel 3. Nilai Parameter Massa Jenis BBM Alternatif Sampah Plastik

\begin{tabular}{cccc}
\hline Jenis & Sampel & $\begin{array}{c}\text { Massa Jenis } \\
\text { (gram/mL) }\end{array}$ & $\begin{array}{c}\text { Rata -rata Massa Jenis } \\
\text { (gram/mL) }\end{array}$ \\
\hline \multirow{2}{*}{ LDPE } & I & 0,7348 & \\
& II & 0,7365 & 0,7422 \\
III & 0,7341 & \\
PP & I & 0,7425 & 0,7351 \\
& II & 0,7417 & \\
\hline
\end{tabular}


Tabel 3 menunjukkan seluruh sampel dari kedua jenis plastik baik LDPE maupun PP memiliki nilai massa jenis yang berkisar antara $0,7341-0,7425 \mathrm{~kg} / \mathrm{L}$. Nilai massa jenis dengan kisaran $0,7341-0,7425 \mathrm{~kg} / \mathrm{L}$ merupakan kisaran nilai massa jenis yang mendekati nilai massa jenis bensin yaitu $0,7100-0,7700 \mathrm{~kg} / \mathrm{L}$.

Tabel 4. Nilai Parameter Viskositas BBM Alternatif Sampah Plastik

\begin{tabular}{cccc}
\hline Jenis & Sampel & $\begin{array}{c}\text { Viskositas } \\
\text { (gram/ml) }\end{array}$ & $\begin{array}{c}\text { Rata -rata Viskositas } \\
\text { (gram/ml) }\end{array}$ \\
\hline \multirow{2}{*}{ LDPE } & I & 0,8400 & \\
& II & 0,7000 & 0,7800 \\
III & 0,8000 & \\
I PP & II & 0,6800 & 0,7067 \\
& III & 0,7300 & \\
\hline
\end{tabular}

Nilai viskositas BBM alternatif dari kedua jenis sampel plastik LDPE maupun PP disajikan pada Tabel 4. Nilai viskositas yang dihasilkan dari proses pirolisis pada sampel LDPE dan PP memiliki nilai yang cukup rendah yaitu berada pada rentang 0,68-0,84 cP. Perbedaan nilai viskositas pada sampel LDPE dan PP diakibatkan oleh karakteristik sampel yang berbeda yaitu pada sifat titik leleh dan titik embun. Jenis fluida ini sangat cocok digunakan sebagai bahan bakar karena mampu mengalir di dalam mesin kendaraan disebabkan viskositas yang rendah. Menurut Apriani (2013) nilai viskositas merupakan sifat cairan yang berhubungan erat dengan hambatan untuk mengalir. Beberapa cairan ada yang dapat mengalir cepat, sedangkan lainnya mengalir secara lambat. Cairan yang mengalir cepat seperti air, alkohol dan bensin mempunyai viskositas kecil. Nilai viskositas dari kedua sampel BBM alternatif tersebut mendekati nilai viskositas bahan bakar bensin, yaitu sebesar 0,652 cP.

\section{KONSISTENSI NILAI PARAMETER FISIK BBM ALTERNATIF HASIL PIROLISIS}

Pengujian konsistensi nilai parameter fisik BBM alternatif hasil pirolisis dengan Uji Mann Whitney menggunakan software MiniTab14. Software ini menyediakan berbagai jenis perintah yang memungkinkan proses pemasukan data, manipulasi data, pembuatan grafik dan berbagai analisis statistik.

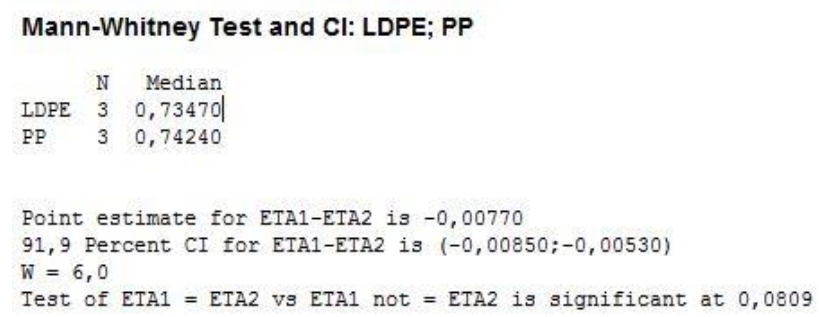

Gambar 4. Hasil uji Mann Whitney untuk parameter massa jenis

Berdasarkan hasil uji Mann Whitney untuk parameter massa jenis, didapatkan nilai signifikansi sebesar 0,0809 yang disajikan pada Gambar 4. Nilai ini menunjukkan tidak terdapat perbedaan Mean dan Median yang bermakna antara variabel LDPE dan PP. Sehingga dapat disimpulkan bahwa tidak ada perbedaan nyata antara sampel LDPE dan PP berdasarkan kualitas dengan parameter massa jenis. Hasil pengujian statistik ini sama dengan hasil pengujian yang menunjukkan bahwa nilai massa jenis sampel PP dan LDPE memiliki nilai yang sama dikisaran nilai massa jenis bensin yaitu 0,7100-0,7700 Kg/L. 


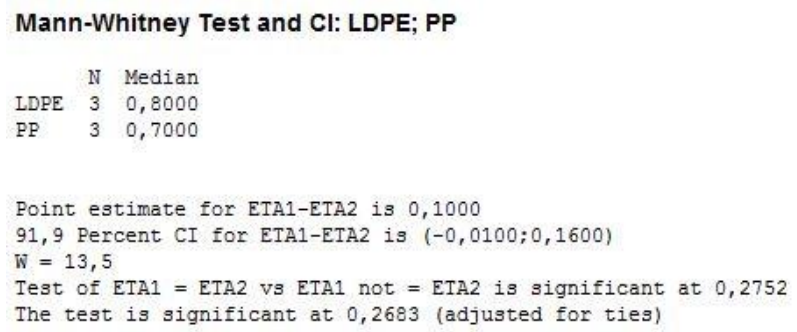

Gambar 5. Hasil uji Mann Whitney untuk parameter viskositas

Hasil pengujian Mann Whitney untuk parameter viskositas didapatkan nilai signifikansinya adalah 0,2752 (Gambar 5) di mana nilainya lebih besar dari batas kritis 0,05 sehingga keputusan hipotesis menerima HO. Kesimpulan yang didapat yaitu bahwa tidak ada perbedaan nyata antara sampel PP dan LDPE berdasarkan klasifikasi dengan parameter viskositas, dimana sampel-sampel dari kedua jesnis plastik tersebut memiliki nilai viskositas yang berada pada kisaran yang sama, yang tergolong kedalam klasifikasi minyak premium/bensin.

\section{E. KALKULASI NILAI EKONOMI SAMPAH PLASTIK SETELAH PROSES PIROLISIS}

Kalkulasi perubahan nilai ekonomi sampah plastik non ekonomi dilakukan dengan menghitung biaya yang dikeluarkan selama produksi serta harga produk yang dihasilkan per satuan $1 \mathrm{~kg}$ bahan baku pirolisis yaitu sampah plastik. Satuan $1 \mathrm{~kg}$ sampah digunakan dalam kalkulasi untuk penyetaraan nilai ekonomi sampah yang diterima bank sampah yaitu harga sampah per satuan kg. Kalkulasi secara sederhana dilakukan dengan rumus sebagai berikut:

$$
\text { Nilai ekonomi } / \mathrm{kg}=(\text { harga produk } / 500 \mathrm{~g}-\text { Sbiaya produksi } / 500 \mathrm{~g}) \times 2
$$

Harga produk yang dihasilkan dihitung dengan mengalikan volume BBM alternatif yang dihasilkan dari 500 gram plastik pada satu kali percobaan dengan harga bahan bakar yang terbentuk dan telah diklasifikasikan. Kedua jenis sampel menghasilkan BBM alternatif yang tergolong bahan bakar bensin/premium. Berdasarkan Keputusan Menteri ESDM RI No. 5976 Tahun 2016, harga untuk 1 liter bahan bakar bensin/premium adalah Rp 6.450. Harga produk BBM alternatif dari kedua jenis sampah plastik pada setiap 500 gram sampel sampah plastik yang digunakan dapat dilihat pada Tabel $\mathbf{5}$.

Tabel 5. Harga Produk BBM Alternatif Tiap 500 gram Sampah Plastik

\begin{tabular}{|c|c|c|c|c|}
\hline Sampel & $\begin{array}{l}\text { Volume BBM } \\
\text { Alternatif yang } \\
\text { Dihasilkan }\end{array}$ & $\begin{array}{c}\text { Rerata Volume } \\
\text { BBM Alternatif } \\
\text { Tiap Jenis }\end{array}$ & $\begin{array}{l}\text { Harga } \\
\text { Premium }\end{array}$ & $\begin{array}{c}\text { Harga BBM } \\
\text { Alternatif Tiap } \\
\text { Jenis }\end{array}$ \\
\hline LDPE I & 0,144 liter & & & \\
\hline LDPE II & 0,156 liter & 0,151 liter & Rp 6.450/liter & Rp 973,95 \\
\hline LDPE III & 0,153 liter & & & \\
\hline PPI & 0,475 liter & & & \\
\hline PP II & 0,489 liter & 0,483 liter & Rp 6.450/liter & Rp 3.117,5 \\
\hline PP III & 0,486 liter & & & \\
\hline
\end{tabular}

Biaya produksi adalah biaya operasional yang dihabiskan dalam 1 kali proses pirolisis. Biaya produksi meliputi biaya penggunaan volume gas LPG, biaya balok es yang dibutuhkan, serta biaya total daya listrik untuk pompa air. Rincian biaya produksi selama proses pirolisis sampah plastik dengan massa 500 gram disajikan dalam Tabel 6. 
Tabel 6. Rincian Biaya Produksi

\begin{tabular}{lcr}
\hline \multicolumn{1}{c}{ Keperluan } & \multicolumn{3}{c}{$\begin{array}{c}\text { Biaya Produksi / } \mathbf{5 0 0} \mathbf{g} \\
\text { sampah plastik }\end{array}$} \\
\hline Gas LPG & $\mathrm{Rp}$ & 1.997 \\
Es Balok & $\mathrm{Rp}$ & 1.000 \\
Pompa Air & $\mathrm{Rp}$ & 14 \\
Total & $\mathrm{Rp}$ & $\mathbf{3 . 0 1 1}$ \\
\hline
\end{tabular}

Kalkulasi nilai ekonomi dari sampah non ekonomis dihitung sesuai dengan kuantitas produk BBM alternatif hasil pirolisis dari sampah plastik LDPE dan PP dan harga BBM tersebut berdasarkan klasifikasinya. Rekapitulasi perhitungan nilai ekonomi sampah plastik non ekonomis setelah proses pirolisis dari kedua jenis sampah plastik yang diuji disajikan dalam Tabel 7.

Tabel 7. Nilai Ekonomi Sampah Non Ekonomis Sampah Plastik LDPE dan PP

\begin{tabular}{cccccc}
\hline $\begin{array}{c}\text { Jenis } \\
\text { Sampah } \\
\text { Plastik }\end{array}$ & $\begin{array}{c}\text { Harga BBM } \\
\text { Alternatif } \\
\text { per } \mathbf{5 0 0} \mathbf{g} \\
\text { sampah } \\
\text { plastik }\end{array}$ & $\begin{array}{c}\text { Biaya } \\
\text { Produksi/ } \\
\mathbf{5 0 0} \mathbf{g}\end{array}$ & $\begin{array}{c}\text { Nilai } \\
\text { Ekonomi } \\
\text { per } \\
\text { Produksi/ } \\
\mathbf{5 0 0} \mathbf{g}\end{array}$ & $\begin{array}{c}\text { Jumlah } \\
\text { Produksi } \\
\mathbf{1} \mathbf{~ k g} \\
\text { Plastik }\end{array}$ & Nilai Ekonomi per Kg \\
\hline LDPE & Rp 973,95 & Rp 3.011 & $\begin{array}{c}- \text { Rp 2.037 } \\
\text { Rp 107,5 }\end{array}$ & 2 kali & - Rp 4.074 \\
PP & Rp 3.117,5 & & Rp 215 \\
\hline
\end{tabular}

Berdasarkan Tabel 4.7 nilai ekonomi sampah plastik PP berupa sedotan plastik memiliki nilai ekonomi sebesar Rp 215/kg sedangkan sampah plastik LDPE berupa kantong plastik tidak memiliki keuntungan nilai ekonomi karena nilai ekonominya turun menjadi -Rp 4.074/kg. Rendahnya nilai ekonomi sampah LDPE disebabkan sedikitnya volume BBM alternatif yang dihasilkan selama pirolisis, mengingat suhu yang digunakan pada pirolisis sampah plastik tidak cukup tinggi bagi jenis plastik LDPE.

\section{KESIMPULAN}

Adapun simpulan yang dapat dipaparkan antara lain:

1. Kuantitas volume BBM alternatif yang dihasilkan dari sampah plastik dengan massa 500 gram dari jenis plastik LDPE berupa kantong plastik yaitu $141 \mathrm{~mL}, 156 \mathrm{~mL}, 153$ $\mathrm{mL}$ dengan rata-rata volume $151 \mathrm{~mL}$, sedangkan dari jenis plastik PP berupa sedotan yaitu sebesar $483 \mathrm{~mL} 475 \mathrm{~mL}, 489 \mathrm{~mL}, 486 \mathrm{~mL}$ dengan rata-rata volume $483 \mathrm{~mL}$. Kedua BBM alternatif yang dihasilkan dari sampah plastik LDPE maupun PP tergolong sebagai bahan bakar premium/bensin.

2. Kualitas BBM alternatif jenis plastik LDPE dan PP berdasarkan hasil pengujian, nilai massa jenis BBM alternatif jenis plastik LDPE pada 3 sampel yaitu 0,7348 kg/L, $0,7365 \mathrm{~kg} / \mathrm{L}, 0,7341 \mathrm{~kg} / \mathrm{L}$, sedangkan pada jenis plastik PP nilai massa jenisnya pada 3 sampel yaitu $0,7425 \mathrm{~kg} / \mathrm{L}, 0,7417 \mathrm{~kg} / \mathrm{L}, 0,7424 \mathrm{~kg} / \mathrm{L}$. Nilai massa jenis ini merupakan nilai massa jenis golongan bensin yaitu dengan nilai massa jenis 0,7100 $-0,7700 \mathrm{~kg} / \mathrm{L}$. Hasil pengujian nilai viskositas BBM alternatif jenis plastik LDPE pada 3 sampel yaitu $0,8400 \mathrm{cP}, 0,7000 \mathrm{cP}, 0,8000 \mathrm{cP}$, sedangkan pada jenis plastik PP nilai viskositas pada 3 sampel yaitu $0,6800 \mathrm{cP}, 0,7300 \mathrm{cP}, 0,7100 \mathrm{cP}$. Nilai viskositas ini merupakan nilai viskositas golongan bahan bakar bensin yaitu dengan nilai viskositas 0,6520 cP. Kedua BBM alternatif yang dihasilkan dari sampah plastik LDPE 
maupun PP tergolong sebagai kualitas bahan bakar premium/bensin. Berdasarkan uji stastistik Mann Whitney, kualitas BBM alternatif berdasarkan parameter fisik jenis plastik LDPE maupun PP memiliki angka signifkasi $>0,05$ yang artinya kedua sampel plastik jenis LDEP dan PP tidak ada perbedaan nyata antara sampel LDPE dan PP.

3. Nilai ekonomi pada kedua jenis sampah berubah setelah melalui proses pirolisis. Sampah plastik PP berupa sedotan plastik akan memiliki nilai ekonomi sebesar Rp $215 / \mathrm{kg}$, sedangkan sampah plastik LDPE berupa kantong plastik memiliki nilai ekonomi -Rp 4.074/kg karena biaya produksi BBM alternatif dari kantong plastik melebihi nilai jual produk yang dihasilkan.

\section{UCAPAN TERIMA KASIH}

Terima kasih kepada dosen pembimbing skripsi, Bapak Dr. Arifin, S.T., M.Eng.Sc dan Bapak Dr. Andi Hairil Alimuddin, serta dosen penguji skripsi, Bapak Dr. Ari Widiyantoro, S.Si.,M.Si. dan Ibu Ochih Saziati, S.Si.,M.Sc., Community Development and Outreaching Univeristas Tanjungpura, serta semua pihak yang terlibat dan membantu penulis selama proses pengerjaan penelitian yang tidak dapat diucapkan satu persatu.

\section{DAFTAR PUSTAKA}

Apriani, D. 2013. Studi Tentang Nilai Viskositas Madu Hutan Dari Beberapa Daerah Di Sumatera Barat Untuk Mengetahui Kualitas Madu. Pillar of Physics. Vol. 2. HIm. 91-98.

Keputusan Menteri Energi dan Sumber Daya Mineral Republik Indonesia Nomor:5976 K/12/Mem/2016 Tentang Harga Jual Eceran Jenis Bahan Bakar Minyak Tertentu Dan Jenis Bahan Bakar Minyak Khusus Penugasan.

Maflahah, I. 2010. Analisis Proses Pembuatan Pati Jagung (Maizena) Berbasis Neraca Massa. Jurnal Embryo. Vol 7 (I). HIm 40-45.

Rachmawati, Q., dan Herumurti, W. 2015. Pengolahan Sampah secara Pirolisis dengan Variasi Rasio Komposisi Sampah dan Jenis Plastik. Jurnal Teknik ITS. Vol.4 (I). HIm D27-D29.

Ramadhan, A. dan Munawar A. 2013. Pengolahan Sampah Plastik Menjadi Minyak Menggunakan Proses Pirolisis. Jurnal IImiah Teknik Lingkungan. Vol. 4 (I). HIm 44-52.

Santoso, J. 2010. Uji Sifat Minyak Pirolisis dan Uji Performasi Kompor Berbahan Bakar Minyak Pirolisis dari Sampah Plastik. Skripsi. Surakarta: Universitas Sebelas Maret

Thahir, R.; Alwathan; dan Mustafa. 2013. Spesifikasi dan Analisa Kualitas Bahan Bakar Hasil Pirolisis Sampah Plastik Jenis Polypropylene. Jurnal Teknologi Pengelolaan Limbah (Journal of Waste Management Technology). Vol. 16. HIm 153-158.

Tranggono, S., B. Setiadji, P. Darmadji, Supranto, dan Sudarmanto. 1997. Identifikasi Asap Cair dari Berbagai Jenis Kayu dan Tempurung Kelapa, dalam Wijaya, M., Noor, E., Irawadi. T.T., Pari., G. 2008. Perubahan Suhu Pirolisis Terhadap Struktur Kimia Asap Cair dari Serbuk Gergaji Kayu Pinus. Jurnal Ilmu dan Teknologi Hasil Hutan, Vol. 2, HIm 73-77.

Wirakartakusumah A. 1989. Prinsip Teknik Pangan. PAU Pangan dan Gizi. Bogor: Insitut Pertanian Bogor 